\title{
LITERACY OF BIOLOGY TEACHERS ON SUPPORTIVE MEASURES DURING THE BIOLOGY LEARNING PROCESS FOR PRIMARY SCHOOL STUDENTS WITH LEARNING DISABILITIES
}

\author{
Inta Krauja-Kindzule \\ University of Latvia, Latvia
}

\begin{abstract}
In recent years there has been a lot of discussion about the students' rights to equal educational quality. Several international documents and reports as well as Latvia's Education Development Guidelines 2014-2020 envisage provision of inclusive and equitable quality education, reaching the maximum potential of each student according to his/her abilities, willingness and effort, not circumstances the student (also the teacher and parents) have no influence over. Inclusive education is also one of the six education principles included in the project "Competency Based Curriculum" by the National Centre for Education of the Republic of Latvia. Although in Latvia, as well as in other countries around the world, inclusive education is talked about a lot, the actual level of inclusion measured by the international research project OECD PISA 2015 is low and students with disabilities are still segregated. Teachers often lack professional knowledge and skills for working with students with learning disabilities; teachers of biology and natural sciences do not have enough specific recommendations and sample materials to provide adequate support measures for students with learning disabilities. The aim of this paper is to study the literacy of biology teachers at mainstream education schools on the support measures required by primary school students with learning disabilities during the biology learning process. The author analyzed legislative documents, statistics and scientific literature; developed a questionnaire and surveyed biology teachers working in mainstream education schools and summarized the results of the study. The empirical part of research determined the level of biology teachers' literacy of supportive measures required by students with learning disabilities. The results suggest that biology teachers are able to choose the support measures required by students with learning disabilities during the biology learning process and they know how to provide these support measures according to their knowledge and experience. However, they are not able to use their knowledge and experience to offer and provide support measures tailored to each individual student.
\end{abstract}

Keywords: learning disabilities, support measures, biology teachers, literacy, biology learning process. 


\section{Introduction}

In recent years there has been a lot of discussion about the students' rights to equal educational quality, including in the Sustainable Development Goals adopted by the United Nations in 2015 (United Nations..., 2017) with Goal 4 asking all countries to ensure inclusive and equitable quality education and promote life-long learning opportunities for all. Similar principles of equitable education are included in several other international documents and reports, e.g. UNESCO Convention against Discrimination in Education in 1960 (Convention against Discrimination in Education, 1960); UN Convention on the Rights of the Child in 1989 (UN Convention on the Rights of the Child in 1989, 1989); World Declaration on Education for All in 1990 (World Declaration on Education for All in 1990, 1995); the Salamanca Statement and Framework for Action on Special Needs Education in 1994 (The Salamanca Statement and Framework for Action on Special Needs Education,1994); UNESCO General Conference in 2017 (UNESCO, 2017). Education is an important factor in achieving social inclusion and independence of people, especially people with disabilities, as discussed in the Implementation Guidelines of the UN Convention on the Rights of Persons with Disabilities for 2014-2020 (Implementation Guidelines of the UN Convention on the Rights of Persons with Disabilities for 2014-2020, 2013).

The international OECD PISA (Geske et al., 2015) study emphasizes that inclusive and equitable quality education, means the ability to reach the maximum potential of each student according to his/her abilities, willingness and effort, not circumstances the student (also the teacher and parents) have no influence over. The description of curriculum and educational processes in the project "Competency Based Curriculum" (NCE, 2017a) by National Centre for Education of the Republic of Latvia (NCE) lists inclusive education as one of the six educational principles, defining it as appreciation and recognition of student diversity, meeting the various learning needs in an open study process, using versatile methods and approaches and ensuring a safe and supportive environment with no discrimination.

According to the data available from NCE (Rascevska et al., 2017) about the academic year of 2016/2017, 6172 students with special needs were studying in mainstream education schools, comprising $2.87 \%$ of the total number of students. Of these students with special needs, $69.57 \%$ had learning disabilities.

The author of this study is an actively teaching biology teacher in two mainstream education schools and has everyday experience with primary school students with learning disabilities. The author believes 
that teachers lack professional knowledge and skills for working with students with learning disabilities. Based on personal experience acquired as a biology teacher and the data obtained from the study "A Study on the Cost Model for Support Services for Children with Special Needs in the Context of Inclusive Education" (Rascevska et al., 2017), it can be argued that teachers of biology and natural sciences do not have enough specific recommendations and sample materials to provide adequate support measures for students with learning disabilities. Thus, the aim of this paper is to study the literacy of the biology teachers at mainstream education schools on support measures required by primary school students with learning disabilities during the biology learning process. Two research questions were put forward. First, what characterizes the literacy of biology teachers on support measures required by primary school students with learning disabilities during the biology learning process? Second, how do biology teachers rate their literacy on providing the support measures required by primary school students with learning disabilities during the biology learning process?

To achieve this aim legislative documents, statistics and scientific literature were analyzed, a questionnaire was developed and biology teachers working in mainstream education schools were surveyed; results of the study were summarized.

\section{Theoretical background}

\section{Support measures for students with learning disabilities in mainstream education schools}

The term "learning disabilities" is relatively new, although signs of learning disabilities have been described more than a century ago. It was first used by Samuel Kirk (Kirk, 1963) in Chicago Conference of Exploration into Problems of the Perceptually Handicapped Child in 1963. Nowadays there are several definitions of learning disabilities. Dictionary of Speech Therapy terms (Luse et al., 2012) defines learning disabilities as "neurological disorders influencing the ability of the brain to understand, remember or transfer information." A similar definition is provided in Encyclopedia of Learning Disabilities (Turkington and Harris, 2006), Learning Disabilities Association of America (Learning Disabilities..., 2018) and authors Fletcher, Lyon, Fuchs and Barnes (Fletcher, Lyon, 2019), who describe learning disabilities as neurobiological disabilities caused by structural or operational differences of the human brain. Learning disabilities can mean a person has difficulties in connection with thinking, memory, perception, attention, speaking, reading, writing, pronunciation and calculation processes, social skills and emotional maturity. 
It is important to note that learning disabilities are not synonymous to mental development disorders, autism spectrum disorders, hearing and/ or vision impairment and behavioural disorders (Gartland, Strosnider, 2017). The term "learning difficulties" is sometimes used, but it should not be considered synonymous to "learning disabilities", because learning difficulties can have reasons other than neurobiological disorders of the brain (Demidova, 2008; Gartland, Strosnider, 2017). The term "specific learning disorder" is not used in this study as it is more commonly used in medicine, while teachers in their field of work use the term "learning disabilities".

It is crucial to identify that a child has learning disabilities as soon as possible, to provide the necessary support in a timely manner and the child can be successful in school and life. There are lists of warning signs for learning disabilities in various age groups. A summary of possible warning signs for adolescence was made, as the aim of this research is to study the literacy of biology teachers on the support measures required by primary school students with learning disabilities.

Combining the information provided by various authors (Smita, Strika, 1998; Turkington, Harris, 2006; Kemp et al., 2019), teenagers with learning disabilities can have problems/difficulties with: learning new words, terms; using full sentences; understanding the structure of a conversation; retelling; expressing thoughts; memorizing facts and information; remembering routines; comprehension of materials they have read; mathematical calculations; handwriting; drawing or retracing shapes; following instructions; self-esteem; communication with peers; distinguishing between important and trivial things; voice modulation; accuracy and organization; change of activities.

Most of the students with learning disabilities will have problems/ difficulties with specific tasks, e.g. one student might have difficulties with calculation and coordination, another one might have difficulties with text comprehension and writing. Taking into consideration the various manifestations of learning disabilities, the diagnostic process is difficult. Regulations of the Cabinet of Ministers No. 709 (Regulations on Pedagogical-Medical Commissions, 2012) state that only the National Educational Medical Commission has the right to issue a conclusion about the most appropriate special primary education programme for students with learning disabilities from Year 5 to Year 9. A study by Rascevska, Nimante, Umbrasko, Sumane, Martinsone, Zukovska (Rascevska et al., 2017) concluded that the special educational needs of students in Latvia are still determining and recognized using a medical approach to education.

In order to help students with special needs to overcome the hurdles in learning created by their health problems or developmental disorders, 
various additional activities and methods i.e. support measures should be used within the learning process of these students (NCE, 2019). Laws and regulations have set the process of assigning support measures to students in Latvia. If a student is diagnosed with a learning disability, the school has to license a special primary education programmes for students with learning disabilities, however often the disabilities are not diagnosed or the official document does not reach the school administration for some other reason. Regardless of whether a student with learning disabilities acquires primary education following a basic primary education programme or a special primary education programme for students with learning disabilities, it is necessary for the student to provide support measures for the success of the learning process. To accomplish that during the biology learning process, biology teachers have to provide these students with support measures, meaning they have to find additional ways, measures and methods within the biology learning process to compensate for the learning disabilities of their students. All support measures provided to the student have to be included in the Individual Plan for Acquisition of Educational Programme (individual education plan or IEP). IEP is developed in cooperation between the support personnel, the student, his/her parents and teachers (NCE, 2017b). According to the procedure described in the Regulations of the Cabinet of Ministers No. 335 (Regulations on the Content and Procedure of Centralized Examinations, 2010) and No. 1510 (State Examination Procedure, 2013), students are entitled to support measures during the examinations when finishing Year 9.

Support measures include a set of various activities and methods that can include adjusting the study environment, methods, materials, homework, tests and time planning. When assigning support measures for a student with learning disabilities, several things should be taken into consideration: the opinion of the student (he/she has to understand the meaning of each support measure); support measures have to be based on evaluation of each student; the information about this student that teachers, parents as well as other people who know this student's needs and strengths have; adequacy of the study environment; do specific support measures correspond to the needs of the student (British Columbia..., 2011; Michaele, 2013; NCE, 2019).

Support measures can be divided into several groups based on their type. Most often support measures are classified as: support measures for receiving information; for preparation of answers and answering; working environment; time for completion of tasks and sequence of tasks (NCE, 2019). The author of this paper suggests grouping support measures by their timing (support measures provided throughout the learning process; before the learning process; in the first part, middle or end of the learning process; after the learning process) and the fact whether these support measures 
can be used only for the student with learning disabilities or the whole class. Such classification is supported by the fact that teachers of specific subjects are the ones to use support measures during their learning process and the author, being a biology teacher, has concluded from experience that support measures aimed at students with learning disabilities improve the progress of other students as well.

\section{Literacy of biology teachers on the support measures required by students with learning disabilities}

For students with learning disabilities to be successfully included in mainstream education schools and natural sciences classes, Jefferies (2018) notes that the determining factor for successful inclusion of students with learning disabilities into a mainstream education school is the teacher, his/ her attitude, ability to use the correct support measures, understanding of his/her student's weaknesses and strengths and the wish to continue professional development.

Analysing and summarising findings of various authors (Blūma, 2016; Connor, Cavendish, 2018; Education Department of the Ministry of Education and Science, 2018; Praulite, 2008; Rozenfelde, 2016; Rutka, 2012) about the knowledge, skills and attitudes of teachers who are working with students with learning disabilities, it can be concluded that besides knowledge of their subject curriculum and teaching methodology teachers also need:

- willingness to work with students with learning disabilities;

- ability to evaluate the individual development, strengths and weaknesses and learning needs of a student;

- ability to conduct learning process in a way that facilitates the development of all students and their ability to reach their maximum potential;

- readiness to continue professional development in the fields of biology, pedagogy, psychology and legislation, and, also, develop as a personality;

- ability to cooperate and share experiences with colleagues and support personnel;

- knowledge and skills to use support measures for reaching the goals specific to the subject.

In order to determine what elements of literacy are necessary for biology teachers, to provide all the support measures required by primary school students with learning disabilities, the author has developed descriptions of literacy for biology teachers in four levels on the support measures required by students with learning disabilities (Table 1). 
Table 1. Levels of Literacy of Biology Teachers on Support Measures Required by Students with Learning Disabilities (author's design, based on Uno, Bybee, 1994; Uno, 1999)

\begin{tabular}{|l|l|}
\hline \multicolumn{1}{|c|}{ Level } & \multicolumn{1}{c|}{ Description } \\
\hline Nominal & $\begin{array}{l}\text { Identifies/recognises the terms "learning disabilities" and } \\
\text { "support measures". } \\
\text { Is able to provide partial descriptions of the terms, can have } \\
\text { misconceptions about the meaning of these terms, lacks } \\
\text { comprehension. }\end{array}$ \\
\hline Functional & $\begin{array}{l}\text { Is able to define the terms "learning disabilities" and "support } \\
\text { measures", they are part of vocabulary. Knows about signs of } \\
\text { learning disabilities and types of support measures. } \\
\text { Lacks deeper understanding of the terms, little/no personal } \\
\text { experience. }\end{array}$ \\
\hline Structural & $\begin{array}{l}\text { Is able to use his/her own words to describe and explain } \\
\text { the terms "learning disabilities" and "support measures". } \\
\text { Knows and recognises signs of learning disabilities; and } \\
\text { knows how to select the necessary support measures: } \\
\text { makes support measures meaningful based on his/her own } \\
\text { knowledge and experience. }\end{array}$ \\
\hline $\begin{array}{l}\text { Multi- } \\
\text { dimensional }\end{array}$ & $\begin{array}{l}\text { Knows the history and essence of learning disabilities and } \\
\text { support measures. Is able to study the ways a student's } \\
\text { learning disabilities manifest, can collect all the necessary } \\
\text { information. Using this information and his/her experience, } \\
\text { is able to offer and provide support measures required by } \\
\text { the student. } \\
\text { Has interdisciplinary knowledge, including knowledge } \\
\text { from the fields of medicine and psychology about learning } \\
\text { disabilities and support measures. } \\
\text { Tendency towards life-long learning: continuous improvement } \\
\text { of knowledge and skills on support measures for students } \\
\text { with learning disabilities. }\end{array}$ \\
\hline
\end{tabular}

The empirical part of research was carried out based on the author's developed levels of literacy of biology teachers on the support measures required by students with learning disabilities.

\section{Methodology}

This research was a quantitative non-experimental descriptive study using a survey method: a questionnaire. The study was carried out from September of 2017 to May of 2019 and it can be divided into four stages (Figure 1). 


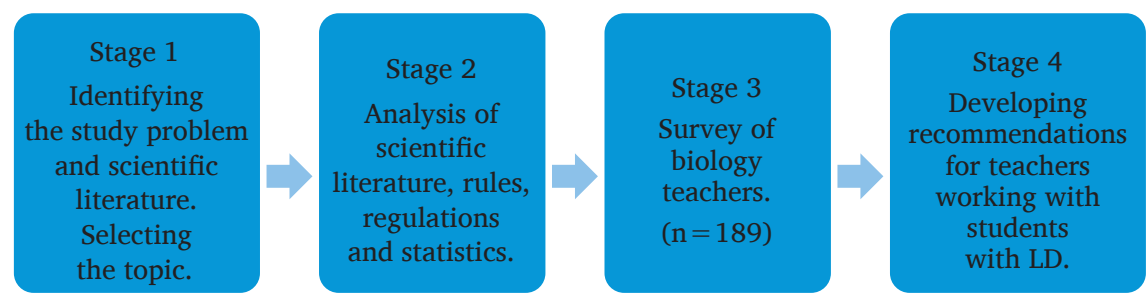

Figure 1. Research Methodology (author's design)

During Stage 3 "Survey of biology teachers" author developed a questionnaire based on information gathered from scientific literature and carried out a survey of biology teachers of mainstream education schools on support measures for students with learning disabilities during the biology learning process (Figure 2).
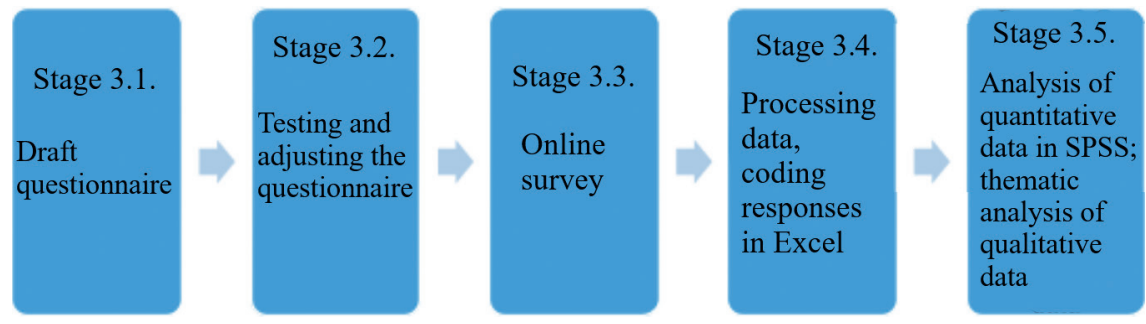

Figure 2. Detailed Description of Stage 3 - Survey (author's design)

Survey consisted of five stages:

1. Developing a draft questionnaire in Google Forms. Survey was aimed at biology teachers from mainstream education schools who were or had been teaching biology for primary school students. The questionnaire consisted of 19 closed questions (five of which are Likert scale questions with four or five answer options) and one open-end question. Questions could be grouped by their type and level of literacy.

2. Testing and adjusting the questionnaire. After the draft questionnaire was created, it was filled in online by two biology teachers with preliminary knowledge of creating surveys using Google Forms. After completing the questionnaire, teachers gave written feedback about improvements to the questionnaire. The author considered the suggestions and made adjustments to the questionnaire.

3. Online survey. Questionnaires were sent from the author's email to the email addresses of selected 617 mainstream education schools (Ministry of Education and Science, 2018), with the request to pass them on to biology teachers. It was possible to fill in the questionnaire online for 8 weeks. 189 biology teachers participated in the survey during this time period. 
4. Processing of received responses and coding them in Microsoft Excel. Responses were coded assigning a number to possible responses.

5. Analysis of data using SPSS.

5.1. Creating a matrix in SPSS "Variable View" (input of questions and possible answer codes); importing coded data from Excel to SPSS "Data View"; analysis of data - for Likert scale questions (data validity, spread of variables, correlations); basic data analysis (binary data etc.) - cross tabulation; mean; standard deviation.

5.2. Thematic analysis of qualitative data from the survey. Analysis of answers to question 20 (open-end question), using thematic analysis - a method to analyse qualitative data.

\section{Results of the Survey}

Respondents of the survey were biology teachers from mainstream educational schools teaching biology to students of Years 7 to 9 (ages 13-16). The survey was completed by 189 respondents, 95.24\% $(n=180)$ of which were female and $4.76 \%(n=9)$ - male. The largest group of respondents (34.39\% or 65 teachers) had been working as biology teachers already for 21-30 years. The second largest group (32.28\% or 61 teacher) had been working as biology teachers for more than 30 years. The smallest group (4.76\% or 9 out of 189 biology teachers) had been working for 6-10 years. Data received in this survey partially corresponds to data from TALIS 2013 (Geske et al., 2015) where 16\% of teachers were working less than 10 years (this research: $14.28 \%$ ), working $11-20$ years $-28 \%$ of teachers (this research: $19.05 \%$ ) and working more than 20 years - 56\% of teachers (this research: 66.67\%). The author explains these differences by the fact that TALIS research was carried out 6 years ago and the percentage of teachers working more than 20 years has increased over time, because the teaching force in Latvia is ageing.

Analysis of further data showed that:

1. The literacy of biology teachers on support measures required by students with learning disabilities corresponds to the nominal level as:

- Teachers identify/recognize the term "learning disabilities", because almost $80 \%$ of biology teachers admit that they have been or are currently teaching students with learning disabilities. Teachers are mostly informed about students with learning disabilities in their class, especially if these disabilities are officially diagnosed and recognized.

2. The literacy of biology teachers on support measures required by students with learning disabilities corresponds to the functional level as:

- Teachers know the signs of learning disabilities, noting that the most common difficulties are connected to attention span, reading and 
writing. Least common difficulties - coordination and thinking (processing visual information).

3. The literacy of biology teachers on support measures required by students with learning disabilities corresponds to the structural level as:

- Teachers know and recognize signs of learning disabilities, and based on their knowledge and skills know how to select the necessary support measures: the support measures most often used during learning and tests by biology teachers were additional consultations, additional time and use of prompts/word mats, however there is a partial lack of correspondence between the manifested learning disabilities biology teachers have encountered and the support measures most often provided to students with learning disabilities. This indicates a partial correspondence to the structural level of literacy.

- There is no correlation with support measures that require more effort, time and other resources from the teacher, are more complicated, require more skills and higher level of competence. Due to this, teachers more often use support measures like additional consultations, which are voluntary, and the student could decide not to attend them; seating the student in the first row and allowing to use prompts/word mats.

- One fifth of respondents noted that the support measures offered to students are formal and almost a third - that the school creates IEP for students with learning disabilities. However, these plans are formal and are not developed on the basis of experiences, skills and differences in the learning processes of different students, which indicates that there is a lack of deeper understanding.

- Not all biology teachers are active participants in the development of IEP. In general, approximately a fifth of biology teachers answered that they do not know about it or they think IEP are not being made. Biology teachers cooperate with other teachers to ensure a successful learning process for students with learning disabilities and attend various educational courses to improve their literacy on working with students with learning disabilities.

- Regardless of the time they have worked as biology teachers, all teachers require additional professional skills and knowledge for teaching biology to students with learning disabilities.

4. The literacy of biology teachers on support measures required by students with learning disabilities does not correspond to the multidimensional level as:

- The support measures used most often by teachers during learning and in tests are additional consultations, additional time and 
use of prompts/word mats, however there is a partial lack of correspondence between the manifested learning disabilities biology teachers have encountered and the support measures most often provided to students with learning disabilities.

- Some teachers admit that they are not able to tailor individual support measures to students with learning disabilities, because they are not knowledgeable enough to make adjustments to the learning process and they expect support personnel to step in. Basically, there is a risk that students with learning disabilities could not get support as soon as they need it.

- In all groups except teachers who had been working for 11-20 years, there were some teachers who do not consider it to be the job of mainstream education teachers to be teaching students with learning disabilities. Part of the teachers with more years of working experience agree that they wait for the specialists to give them instructions about what to do.

\section{Conclusions}

Answering the research question: "What characterizes the literacy of biology teachers on support measures required by primary school students with learning disabilities during the biology learning process?", the author concludes that it can be characterized by four levels of literacy: nominal, functional, structural and multidimensional. The highest - multidimensional level of literacy of biology teachers is characterized by the ability of teachers to study ways the student's learning disability is manifested, to gather all the necessary information about it; to use all interdisciplinary skills and knowledge to offer and provide the student with support measures corresponding to the needs of the student; constantly continue learning new information and skills about support measures for students with learning disabilities.

Answering the research question: "How do biology teachers rate their literacy about providing the support measures required by primary school students with learning disabilities during the biology learning process?", using data from the empirical study, the author concludes that the level of literacy of biology teachers on support measures required by students with learning disabilities partially corresponds to structural level of literacy, because, firstly, a teacher with structural level of literacy on required support measures will be able to select support measures and use them according to his/her level knowledge and experience; secondly, the discrepancy between the ways learning disabilities manifest mentioned by biology teachers and the support measures chosen most often indicate 
that teachers are not yet able to use their knowledge and skills to offer and provide support measures that are tailored to the requirements of each student, which would be indicative of the highest - multidimensional level of literacy.

\section{References}

Bluma, D. (2016). Skolotāju izglitīiba Latvijā paradigmu mainas kontekstā (1991-2000). Monogrāifiju sērija Izglitibas pētnieciba Latvijā Nr. 9 [Teacher Education in Latvia in Perspective of Paradigm Shift (1991-2000). $9^{\text {th }}$ Monograph of the Series "Educational Research in Latvia"]. Riga: University of Latvia Institute for Educational Research.

British Columbia School Superintendent's Association and Ministry of Education (2011). Supporting Students with Learning Disabilities. A Guide for Teachers. Retrieved from https:// www2.gov.bc.ca/assets/gov/education/kindergarten-to-grade-12/teach/teaching-tools/ inclusive/learning_disabilities_guide.pdf.

Connor, D. J., Cavendish, W. (2018). 'Sit in My Seat': Perspectives of Students with Learning Disabilities about Teacher Effectiveness in High School Inclusive Classrooms. International Journal of Inclusive Education, 1464-5173 (Online). Retrieved from https:// datubazes.lanet.lv:3977/doi/full/10.1080/13603116.2018.1459888.

Convention against Discrimination in Education (1960). Retrieved from http://portal.unesco. org/en/ev.php-URL_ID $=12949 \&$ URL_DO $=$ DO_TOPIC\&URL_SECTION $=201 . \mathrm{html}$.

Demidova, G. (2008). Mācī̌anās traucējumu noteikšana un palīdzỉbas iespējas. Metodiskais materiāls [Identifying Learning Disabilities and Helping Opportunities. Methodical material]. Riga: Education, Youth, and Sports Department of Riga City Council.

Education Department of the Ministry of Education and Science (2018). Profesijas standarts. Skolotājs [Professional Standard. Teacher]. Downloaded from https://visc.gov. lv/profizglitiba/dokumenti/standarti/2017/PS-048.pdf.

Fletcher, J. M., Lyon, G. R., Fuchs, L. S., Barnes, M. A. (2019). Learning Disabilities, Second Edition: From Identification to Intervention. New York: The Guilford press.

Gartland, D., Strosnider, R. (2017). Learning Disabilities and Achieving High-Quality Education Standards. Hammill Institute on Disabilities, Learning Disability Quarterly. Retrieved from https://datubazes.lanet.lv:5054/doi/pdf/10.1177/0731948717696277.

Geske, A., Grinfelds, A., Kangro, A., Kiselova, R., Mihno, L. (2015). Izglïtibas kvalitāte starptautiskā salidzinājumā. Latvija OECD valstu Starptautiskajā skolēnu novērtēšanas programmā [Quality of Education: International Comparison. Latvia in OECD Programme for International Student Assessment]. Edited by Andris Kangro. Riga: University of Latvia.

Implementation Guidelines of the UN Convention on the Rights of Persons with Disabilities for 2014-2020, The Official Gazette of the Republic of Latvia, 231 (5037), (2013). Retrieved from https://likumi.lv/doc.php?id $=262238$.

Jefferies, A. (2018). An Exploration of Teaching Strategies Implemented by Science Teachers for Learning Disabled High School Students. Lamar University: Published by ProQuest LLC. Retrieved from https://search.proquest.com/docview/2150178581.

Kemp, G., Smith, M., Segal, J. (2019). Learning Disabilities and Disorders. Retrieved from https://www.helpguide.org/articles/autism-learning-disabilities/learning-disabilitiesand-disorders.htm?pdf $=12930$. 
Kirk, S. A. (1963). Behavioral diagnosis and remediation of learning disabilities. In Proceedings of the First Annual Conference on Exploration into the Problems of the Perceptually Handicapped. Evanston, IL: Fund for Perceptually Handicapped Children.

World Declaration on Education for All in 1990, No. 181 (1995). Retrieved from https:// www.vestnesis.lv/ta/id/27670.

Learning Disabilities Association of America (2018). Core Principles. What are Learning Disabilities? Retrieved from https://ldaamerica.org/wp-content/uploads/2018/10/LDAWhatAreLDs-CP-10102018.pdf.

Luse, J., Miltina, I., Tubele, S. (2012). Logopēdijas terminu skaidrojošā vārdnīca [Glossary of Speech Therapy Terms]. Riga: RaKa.

Michaele, V. M. (2013). Supporting Students with Learning Disabilities in the General Education Classroom. Monterey Bay: California State University. Retrieved from https:// digitalcommons.csumb.edu/cgi/viewcontent. cgi ?article $=1413 \&$ context $=$ caps_thes.

Ministry of Education and Science (2018). Vispārizglitojošo izglītibas iestāžu kontaktinformācija 2018./2019.m.g. sākumā [Contact Details of General Education Institutions at the Beginning of the 2018 and 2019 School Years]. Downloaded from https://izm. gov.lv/images/izglitiba_visp/Visparizgl_izgl_iest_kontaktinfo_2018_2.xlsx.

NCE (2017a). Izglīîba mūsdienigai lietpratïbai: mācību satura un pieejas apraksts. Projekts Nr. 8.3.1.1./16/I/002 "Kompetenču pieeja mācību saturā" [Education for Modern Expertise: Description of Educational Curriculum and Learning Approach. Project No. 8.3.1.1./16/I/002 "Competency based approach in the curriculum"]. Retrieved from https://www.izm.gov.lv/images/aktualitates/2017/Skola2030Dokuments.pdf.

NCE (2017b). Individuāla pieeja katram skolēnam vispārējās izglītibas iestādēs. Ieteikumi izglïtojamo individuālo kompetenču atbalsta pasākumu plāna izstrādei [Individual Approach to Each Student in General Education Institutions. Recommendations for the Development of a Plan Of Measures to Support Students' Individual Competencies]. Project No. 8.3.2.2/16/I/001. Riga. Retrieved from https://www.tip.edu.lv/media/ files/Ieteikumi_versija_14032017.pdf.

NCE (2019). Atbalsta pasākumu nodrošināšanu vispārējās izglītibas iestādēs. Metodiskais lidzeklis [The Provision of Support Measures in General Education Institutions. Methodical Instrument]. Retrieved from https://visc.gov.lv/specizglitiba/dokumenti/ metmat/metiet_atb_pas_nodr.pdf.

Praulite, G. (2008). Biologíijas mācỉbu metodika [Biology Teaching Methodology]. Riga: RaKa.

Rascevska, M., Nimante, D., Umbrasko, S., Sumane, I., Martinsone, B., Zukovska, I. u. c. (2017). Pētijums par bērniem ar speciālām vajadzïbām sniedzamo atbalsta pakalpojumu izmaksu modeli ieklaujošas izglitïbas istenošanas kontekstā [A Study of the Cost Model of Support Services for Children with Special Needs in the Context of the Implementation of Inclusive Education]. Riga: University of Latvia. Faculty of Education, Psychology and Art. Retrieved from http://www.izm.gov.lv/images/izglitiba_visp/ IZMiepirkumamLUPPMFgalaparskats08122017.pdf.

Regulations on the Content and Procedure of Centralized Examinations, Regulations of the Cabinet of Ministers No. 335, The Official Gazette of the Republic of Latvia, 57 (4249), (2010). Retrieved from https://likumi.lv/doc.php?id= 207788.

Regulations on Pedagogical-Medical Commissions, Regulations of the Cabinet of Ministers No. 709, The Official Gazette of the Republic of Latvia, 165 (4768), (2012). Retrieved from https://likumi.lv/doc.php?id = 252162 . 
Rozenfelde, M. (2016). Skolēnu ar speciālajām vajadzībām iekḷaušanas vispārējās izglītibas iestādēs atbalsta sistēma [Support System for Inclusion of Learners with Special Needs in General Education Institutions]. Riga: University of Latvia. Retrieved from https:// dspace.lu.lv/dspace/bitstream/handle/7/32003/298-55964-Rozenfelde_Marite_ mr16007.pdf? sequence $=1$ \&isAllowed $=\mathrm{y}$.

Rutka, L. (2012). Pedagoga psihologiskā kompetence [Teacher's Psychological Competence]. Riga: RaKa.

Smita, K., Strika, L. (1998). Mācǐšanās traucējumi: no A lìdz Z [Learning Disabilities: A to Z]. Riga: RaKa.

State Examination Procedure, Regulations of the Cabinet of Ministers No. 1510, The Official Gazette of the Republic of Latvia, 253 (5059), (2013). Retrieved from https://likumi.lv/doc.php?id = 263462 .

The Salamanca Statement and Framework for Action on Special Needs Education (1994). Paris: UNESCO.

Turkington, C., Harris, J. R. (2006). THE ENCYCLOPEDIA OF LEARNING DISABILITIES. Second Edition. American Bookworks.

UN Convention on the Rights of the Child in 1989 (1989). Retrieved from https://www. mfa.gov.lv/ministrija/latvijas-parstavis-starptautiskajas-cilvektiesibu-institucijas/ latvijas-republikas-nacionalie-zinojumi-par-starptautisko-konvenciju-izpildi/1989-gadakonvencija-par-berna-tiesibam/1989-gada-konvencija-par-berna-tiesibam.

UNESCO (2017). Latvija Parïzē apliecina apn̦emšanos nodrošināt ieklaujošu, kvalitatīiu un darba tirgum atbilstošu izglitïbu [Latvia in Paris Shows its Commitment to Ensuring Inclusive, Quality and Appropriate Education for the Labour Market]. Retrieved from http://www.unesco.lv/lv/izglitiba/latvija-parize-apliecina-apnemsanos-nodrosinatieklaujosu-kvalitativu-un-darba-tirgum-atbilstosu-izg-1/.

United Nations Development Programme (2017). Sustainable Development Goals. Goal 4: Quality Education. Retrieved from http://www.undp.org/content/undp/en/home/ sustainable-development-goals/goal-4-quality-education.html.

Uno, G. E. (1999). Handbook on Teaching Undergraduate Science Courses: A Survival Training Manual. Retrieved from https://skat.ihmc.us/rid=1JMSTZCBW-147T33619BJ/Handbook\%20on\%20Teaching\%20Undergraduate\%20Science\%20Courses.pdf.

Uno, G. E., Bybee, R. W. (1994). Understanding the Dimensions of Biological Literacy. BioScience, 44(8), 553-557. Retrieved from http://www.jstor.org/stable/1312283 ?seq $=1$ \#page_scan_tab_contents. 